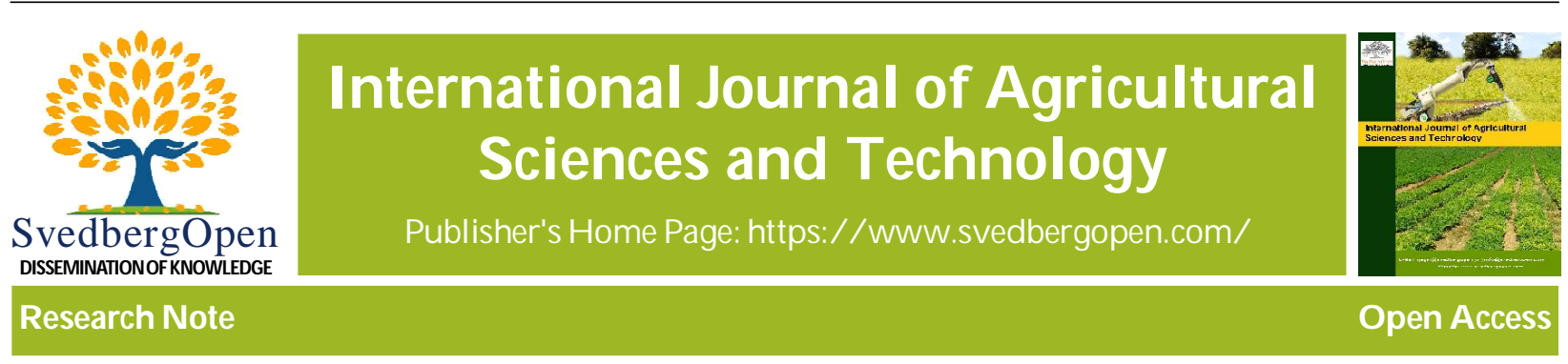

\title{
Management of saline and sodic soils
}

\author{
P. Ramamoorthy ${ }^{1 *}$ M. Karthikeyan² and V. Nirubana ${ }^{3}$
}

${ }^{1} \mathrm{Ph}$. D Scholar, Department of Soil Science \& Agrl. Chemistry, TNAU - Madurai, Tamil Nadu, India. E-mail: ramagri95@gmail.com ${ }^{2}$ Ph. D Scholar, Department of Plant Breeding and Genetics, TNAU - Madurai, Tamil Nadu, India. E-mail: karthiagri819@gmail.com ${ }^{3}$ Senior Research Fellow, Department of Plant Breeding and Genetics, TNAU - Madurai, Tamil Nadu, India. E-mail: nirujayammal@gmail.com

\section{Article Info}

Volume 1, Issue 1, February 2021

Received : 11 November 2020

Accepted : 18 January 2021

Published : 05 February 2021

doi: 10.51483/IJAGST.1.1.2021.24-27

\begin{abstract}
Saline and sodic (alkali) soils can significantly reduce the value and productivity of affected land. By estimation, slightly more than one-fourth of irrigated farmland in the United States is affected by soil salinity. Ions most commonly associated with soil salinity include the anions chloride $\left(\mathrm{Cl}^{-}\right)$, sulfate $\left(\mathrm{SO}_{4}=\right)$, carbonate $\left(\mathrm{HCO}_{3}^{-}\right)$, and sometimes nitrate $\left(\mathrm{NO}_{3}^{-}\right)$ and the cations sodium $\left(\mathrm{Na}^{+}\right)$, calcium $\left(\mathrm{Ca}^{++}\right)$, magnesium $\left(\mathrm{Mg}^{++}\right)$, and sometimes potassium $\left(\mathrm{K}^{+}\right)$. Crops differ in ability to tolerate salt accumulation in soils, but if levels are high enough (more than $16 \mathrm{mS} / \mathrm{cm}$ ), only tolerant plants will survive. As salts accumulate in soil, the soil solution osmotic pressure increases. Reclamation of sodic soils is different; excess sodium must first be replaced by another cation and then leached. Sodic soils are treated by replacing the sodium with calcium from a soluble source.
\end{abstract}

Keywords: Saline soil, Sodic soil, Cations, Anions, Recalamation

(C) 2021 International Journal of Agricultural Sciences and Technology. This is an open access article under the CC BY license (https://creativecommons.org/licenses/by/4.0/), which permits unrestricted use, distribution, and reproduction in any medium, provided you give appropriate credit to the original

author(s) and the source, provide a link to the Creative Commons license, and indicate if changes were made.

\section{Introduction}

Saline and sodic (alkali) soils can significantly reduce the value and productivity of affected land. Soil salinity and related problems generally occur in arid or semiarid climates where rainfall is insufficient to leach soluble salts from the soil or where surface or internal soil drainage is restricted. Salinity problems also can occur on irrigated land, particularly when irrigation water quality is marginal (Bresler et al., 1982).

By estimation, slightly more than one-fourth of irrigated farmland in the United States is affected by soil salinity. In humid regions, salt problems are less likely because rainfall is sufficient to leach soluble salts from the soil, but even in higher rainfall areas, salinity problems occur. In some areas with high water tables, problems may occur with surface evaporation leaving salts to accumulate.

Ions most commonly associated with soil salinity include the anions chloride $\left(\mathrm{Cl}^{-}\right)$, sulfate $\left(\mathrm{SO}_{4}{ }^{=}\right)$, carbonate $\left(\mathrm{HCO}_{3}^{-}\right)$, and sometimes nitrate $\left(\mathrm{NO}_{3}^{-}\right)$and the cations sodium $\left(\mathrm{Na}^{+}\right)$, calcium $\left(\mathrm{Ca}^{++}\right)$, magnesium $\left(\mathrm{Mg}^{++}\right)$, and sometimes potassium $\left(\mathrm{K}^{+}\right)$. Salts of these ions occur in highly variable concentrations and proportions. Salt affected soils have been called white alkali, black alkali, gumbo, slick spots and other descriptive names. These names are associated with soil appearances caused by salt accumulation. The term alkali often refers to soils light in color and prone to surface crusting and implies that affected soils are high in exchangeable sodium (Davis et al., 2014). Salt-affected soils differ considerably in use suitability, productivity, ease of reclamation, and management.

\footnotetext{
* Corresponding author: P. Ramamoorthy, Ph. D scholar, Department of Soil Science \& Agrl. Chemistry, TNAU - Madurai, Tamil Nadu, India. E-mail: ramagri95@gmail.com
} 


\section{Characterization}

Salt-affected soils are divided into three groups based on the amounts and kinds of salts present. Classification depends on total soluble salts (measured by electrical conductivity, EC), soil $\mathrm{pH}$, and exchangeable sodium percentage. Table 1 summarizes the categories: saline, sodic, and saline-sodic. Understanding the differences is critical because these factors determine how the soils should be managed and reclaimed.

\subsection{Saline soils}

All soils contain some water-soluble salts, but when these salts occur in amounts that are harmful to seed germination and plant growth, they are called saline. Saline soils are the easiest of the salt-affected soils to reclaim if good-quality water is available and the site is well drained. Saline soils often are in normal physical condition with good structure and permeability. They are characterized by irregular plant growth and salty white crusts on the soil surface. These salts are mostly sulfates and/or chlorides of calcium and magnesium. Electrical conductivity, abbreviated EC, is the ability of a soil solution to carry electrical current, and salts increase this ability (Chinchmalatpure, 2017). The units that EC is reported in from soil testing laboratories can be given in either milisiemens per centimeter $(\mathrm{mS} / \mathrm{cm})$ or millimhos per centimeter $(\mathrm{mmhos} / \mathrm{cm})$. These units are equal. When a solution extracted from saturated soil is $4.0 \mathrm{mS} / \mathrm{cm}$ or greater, the soil is saline. The $\mathrm{pH}$ of these soils is generally less than 8.5 , and sodium makes up less than $15 \%$ of the exchangeable cations.

\subsection{Sodic soils}

Sodic soils are low in total salts but high in exchangeable sodium. The combination of high levels of sodium and low total salts tends to disperse soil particles, making sodic soils of poor tilth. These soils are sticky when wet, nearly impermeable to water and have a slick look. As they dry, they become hard, cloddy, and crusty. Sodic soils have exchangeable sodium percentages of more than 15 . This means that sodium occupies more than $15 \%$ of the soil's cation exchange capacity (CEC). The $\mathrm{pH}$ is greater than 8.5, and the electrical conductivity is less than $4 \mathrm{mS} / \mathrm{cm}$. Sodic soils are detrimental to growth of most plants (Davis et al., 2014). They can be reclaimed, but it may be slow and expensive due to the lack of a stable soil structure, which slows water drainage.

Table 1: Salt-affected soil classification

\begin{tabular}{|l|c|c|c|c|}
\hline Classification & $\begin{array}{c}\text { Electrical conductivity } \\
(\mathbf{m S / c m})\end{array}$ & Soil $\mathbf{p H}$ & $\begin{array}{c}\text { Exchangeable sodium } \\
\text { percentage }\end{array}$ & Soil physical condition \\
\hline Saline & $>4.0$ & $<8.5$ & $<15$ & Normal \\
\hline Sodic (alkali) & $<4.0$ & $>8.5$ & $>15$ & Poor \\
\hline Saline-sodic & $>4.0$ & $<8.5$ & $>15$ & Normal \\
\hline \multicolumn{5}{|l}{ Source: Batarseh (2017) }
\end{tabular}

\subsection{Saline-sodic soils}

These soils contain large amounts of total soluble salts and greater than $15 \%$ exchangeable sodium. The $\mathrm{pH}$ is generally less than 8.5. Physical properties of these soils are good as long as an excess of soluble salts is present.

\subsection{Salt effects on plant growth}

Crops differ in ability to tolerate salt accumulation in soils, but if levels are high enough (more than $16 \mathrm{mS} / \mathrm{cm}$ ), only tolerant plants will survive. As salts accumulate in soil, the soil solution osmotic pressure increases. When this happens, the amount of water available for plant uptake decreases and plants exhibit poor growth and wilting even though the soil is not dry. Crop selection can be a good management tool for moderately saline soils. Table 2 serves as a general guide of salt-tolerance ratings for crops, realizing that management practices, irrigation water quality, environment, and crop variety also affect tolerance. Just as crops differ in tolerance to high salt concentrations, they also differ in their ability to withstand high sodium concentrations (Batarseh, 2017). Crop growth and development problems on sodic soils can be nutritional (sodium accumulation by plants), associated with poor soil physical conditions, or both. Plants on sodic soils usually show a burning or drying of tissue at leaf edges, progressing inward between veins. General stunting is also common. Crops differ in their ability to tolerate sodic soil, but if sodium levels are high enough, all crops can be affected. Generally, soybeans are quite sensitive, corn and grain sorghum are intermediate and wheat and alfalfa are more 
tolerant. Crested and tall wheatgrass and a few sorghum-sudan hybrids are very tolerant, able to grow on soils with exchangeable sodium percentages above $50 \%$.

\subsection{Soil reclamation}

The first step toward reclaiming any salt-affected soil is an assessment of the soil, including the soil profile. A salt-alkali soil test (available through the KSU Soil Testing Lab) will establish whether the soil is saline, sodic, saline-sodic, or not affected by salts. An examination of the soil profile along with soil survey information helps determine soil permeability characteristics, which are important in leaching salts. In some cases, it may be necessary to facilitate drainage using tile drains or open ditches to allow successful reclamation. Before alteration of the affected area, check with the Natural Resources Conservation Service to be sure the alteration (drainage, etc.) does not violate the wetland conservation provisions of the Food and Security Act of the 1985 Farm Bill as amended. Reclamation may be uneconomical because of poor soil permeability, lack of adequate drainage, or lack of good-quality irrigation water. Often, unless the source of the salt problem can be eliminated or reduced, reclamation will be impossible or, at best, only temporary.

\subsection{Saline soils}

These soils are easy to reclaim for crop production if adequate amounts of low-salt irrigation water or rainfall are available and internal drainage of the soil is good. Saline soils cannot be reclaimed by chemical amendment, conditioner or fertilizer. Reclamation consists of applying enough good-quality water to thoroughly leach excess salts from the soil. Water should be added in sequential applications, allowing time for the soil to drain after each application (Bresler et al., 1982). The quantity of water necessary for reclamation varies with initial salt level, desired salt level, irrigation water quality, and how the water is applied. If sequential applications are used, 8 to 10 inches of leaching water may be necessary to remove $70 \%$ of total salts for each 12 inches of soil to be leached.

\subsection{Sodic and saline-sodic soils}

Reclamation of sodic soils is different; excess sodium must first be replaced by another cation and then leached. Sodic soils are treated by replacing the sodium with calcium from a soluble source. Gypsum $\left(\mathrm{CaSO}_{4} \cdot 2 \mathrm{H}_{2} \mathrm{O}\right)$ is considered the cheapest soluble calcium source for reclamation of sodic soils. On calcareous soils (soils with excess $\mathrm{CaCO} 3$ present), elemental sulfur (S) may be added to furnish calcium indirectly. Sulfur oxidizes in soil to form sulfuric acid, which reacts with the calcium carbonate to form gypsum. Oxidation of elemental sulfur is slow, so this method may be of limited value. Reclamation of a foot depth of sodic soil on one acre requires 1.7 tons of pure gypsum for each milliequivalent of exchangeable sodium present per 100 grams of soil. Once the gypsum is applied and incorporated, sufficient goodquality water must be added to leach the displaced sodium beyond the root zone reported by Jamalkhan et al. (2010). Reclamation of sodic soils is slow because soil structure, once destroyed, is slow to improve. Growing a salt-tolerant crop in the early stages of reclamation and incorporating manure or crop residues adds organic matter, which increases water infiltration and permeability, speeding up the reclamation process (Chinchmalatpure, 2017). In reclamation of saline-sodic soils, the leaching of excess soluble salts must be accompanied (or preceded) by the replacement of exchangeable sodium by calcium. If the excess salts are leached and calcium does not replace the exchangeable sodium, the soil will become sodic.

Table 2: Salt tolerance ratings for various field, forage, and horticultural crops

\begin{tabular}{|l|l|l|l|}
\hline Sensitive (0-4 mS/cm)) & Moderately tolerant $\mathbf{( 4 - 6 ~} \mathbf{~ S / c m})$ & Tolerant (6-8 mS/cm) & Highly tolerant (8-12 mS/cm) \\
\hline Field Beans (Dry) & Corn & Wheat & Barley \\
Red, Ladino, Alsike & Grain Sorghum & Oats & Rye \\
Clovers & Soybean & Triticale & Bermudagrass \\
Strawberry & Bromegrass & Sunflower & Crested Wheatgrass \\
Onion & Sudangrass & Alfalfa & Asparagus \\
Pea & Sorghum-Sudan & Tall Fescue & \\
Carrot & Sweet Clovers & \\
Lettuce, & & \\
Pepper & \multicolumn{2}{|l}{} \\
\hline \multicolumn{2}{|l}{ Source: Jamalkhan et al. (2010) } & \\
\hline
\end{tabular}




\subsection{Reclamation procedure}

Step 1. Collect a soil sample and submit to a soil testing laboratory for a salt-alkali soil test to determine the specific problem.

Step 2. Identify source or cause of the problem.

Step 3. Eliminate the source of salt contamination if possible and establish drainage if necessary.

Step 4. Add chemical amendment (gypsum) to sodic or saline-sodic soils.

Step 5. Incorporate residue to improve water intake.

Step 6. Apply irrigation water (if available).

Step 7. Allow time for leaching and consider planting tolerant crops.

\section{Conclusion}

Salt-affected soils can severely reduce land value and productivity. Soil tests can determine if salt accumulation is a problem. Problems include high total salts (saline soils), excess exchangeable sodium (sodic soils), or both (saline-sodic soils). These soil conditions can severely affect crop growth. Crops react differently to salt-affected soils. Soil reclamation is possible but not always economically feasible.

\section{References}

Batarseh, M. (2017). Sustainable management of calcareous saline sodic soil in arid environment. Journal of Applied and Environmental soil science. Article ID: 1092838.

Bresler, E., Mcneal, B.L. and Carter, D.L. (1982). Saline and sodic soil principles dynamicand modeling. Springer.

Chinchmalatpure, R. (2017). Reclamation and management of salt affected soils for increasing farm productivity and farmers income. ICAR-CSSRI/Bharuch/Technical Manual.

Davis, J.G, Waskom, R.M. and Bauder, T.A. (2014). Managing sodic soils. Colorado State University Extension Publication.

Jamalkhan, M., Jan, M. and Arif, M. (2010). Management of saline and sodic soils through cultural practices and gypsum. Journal of Agricultural Science. 89(1), 81-86.

Cite this article as: P. Ramamoorthy, M. Karthikeyan and V. Nirubana (2021). Management of saline and sodic soils. International Journal of Agricultural Sciences and Technology. 1(1), 24-27. doi: 10.51483/ IJAGST.1.1.2021.24-27. 